\title{
Technology, Technological Domination, and the Great Refusal: Marcuse's Critique of the Advanced Industrial Society
}

Jeffry V. Ocay

$\mathrm{H}$ erbert Marcuse's oenvre is driven by the recurring theme of "emancipation"- that is, the attempt to liberate man from social exploitation and the projection of an alternative society, a socialist society which Marcuse describes as "free, happy, and non-repressive."1 This suggests that Marcuse saw the existing society as pathological and therefore it needs to be diagnosed and remedied. His readings on Marx led him to his initial findings that the capitalist social order is the primordial cause of these pathologies, and, hence, it is the transformation of this social order that can bring emancipation to fruition. Inasmuch as this struggle for emancipation requires an active political agent, a critical theorist is, therefore, bound to seek for this agent. This is precisely what concerned Marcuse in his pre-World War II writings. His theory of historicity, which straddles Heidegger, Hegel, and Marx, is a search for that viable political agent who can be the hope of emancipation. Thus, Marcuse's theory of historicity is premised, among other things, on the attempt to develop a theory of emancipation, and I call this "Marcuse's first theory of emancipation."

Now, we may observe that after Marcuse devised a philosophical model of history that would secure the possibility of such agent of emancipation, his next task is to enunciate how this active political agent can actualize the project of liberation. But after World War II, Marcuse was faced with a huge difficulty: the integration of the proletariat into the status quo as can be seen in the two defining events in contemporary German history, i.e., the defeat of the socialists in the German Revolution of 1918-19 and the support the German proletarians had for Hitler. These events further convinced Marcuse (and the rest of the first generation of critical theorists like Benjamin, Horkheimer, and Adorno) that Marx's proletariat is no longer the primary agent of emancipation. In his analysis, Marcuse realized that the integration of the proletariat into the status quo had something to do with the advancement of technology that contributed to the dawning of the advanced

1 See Jeffry V. Ocay, "Heidegger, Hegel, Marx: Marcuse and the Theory of Historicity," in KRITIKE: An Online Journal of Philosophy, 2:2 (December 2008), 46-64. 
industrial society, a new type of society which reduces individuals into a state of "one-dimensionality." This forced Marcuse to renew his theory of emancipation through a critique of the advanced industrial society. This paper attempts to address this issue.

To have a full appreciation of Marcuse's view on technology in the context of advanced industrial society, a preliminary discussion on the meaning of technology is provided here. Thus, I begin my discussion with a working definition of technology. In doing so, I refer to the work of Mario Bunge, which aptly sets the ground for any attempt to understand the dynamics and implications of technology, be they social, political, or economic. I present succinctly his view on technology. The next part deals with Marcuse's notion of technology. It centers on how technology, which is originally conceived as liberating, has become a tool for domination in the advanced industrial society. Finally, this section closes with a discussion on the Great Refusal, a term which Marcuse believes to be the most appropriate action the individuals need to combat all forms of control and domination and to attain emancipation.

\section{Technology Defined}

Technology is a very familiar term, yet it is a difficult concept to define. As a matter of fact, there is no standing consensus as to what it really is. The layman always equates technology with gadgets or "tools" in general, e.g., the spear, the compass, the automobile, the computer, the mobile phone, and the likes, while some philosophers, like Martin Heidegger, insists that technology cannot be defined. According to Heidegger, what we understand about technology is only the truth which it has revealed. Technology is simply a "way of revealing, bringing-forth" 2 of what he calls "standing-reserve," i.e., of truth, of Being. Thus, for Heidegger, the best way to approach technology is to attune ourselves to the "Being" of technology.

For Mario Bunge, technology is a body of knowledge which is compatible with science and controllable by scientific method, and "can be employed to control, transform or create things or processes, natural or social, to some practical end deemed to be valuable." 3 Therefore, any practiceoriented activity which employs the scientific method is, for Bunge, "technology." This coincides with the general notion of technology as the application of science. In fact, for Bunge, technology is simply "applied science."

Applied science (technology) differs from pure science (science proper) in many respects. Pure science attempts to seek truth for its own sake, while applied science aims for useful truth, truth for a practical purpose. ${ }^{4}$ Whereas pure science wants to understand things better, applied science hopes

\footnotetext{
2 Martin Heidegger, The Question Concerning Technology and Other Essays, trans. by William Lovitt (New York and London: Garland Publishing, 1977), 12.

${ }^{3}$ Mario Bunge, "The Philosophical Richness of Technology," in PSA: Proceedings of the Biennial Meeting of the Philosophy of Science Association, 2 (1976), 154.

${ }^{4}$ Ibid., 158.
} 


\section{TECHNOLOGY, TECHNOLOGICAL DOMINATION}

to improve its mastery over these things. ${ }^{5}$ While pure science involves conceptual knowledge, applied science involves skill or know-how. ${ }^{6}$ The notion of skill or know-how, that is, the practical ability and knowledge to do something is crucial here. This gives us the impression that technology cannot simply be equated with gadgets or tools. Technology as a know-how refers to those patterns of action, in a sense modes of thinking, which enable man to transform knowledge into means for meeting a particular end, e.g., basic human needs. As Bunge asserts, technology involves "controlling," "transforming," and "creating."

While Bunge provides us correct and elemental definition of technology, Heidegger's view that it is not yet "true" seems incontestable. There remains something essential that Bunge's definition has not captured in the term "technology." But, for sure, it is neither Heidegger's notion of "Being" as that which technology reveals. Much more relevant here is the Marxist notion of technology as one of the main forces enabling contemporary capitalism to establish itself, and it is this alliance with capitalism that grants technology its power over individual minds and societies. Douglas Kellner calls this alliance "techno-capitalism," an alliance which "continues to attempt to monopolize new technologies in the interest of corporate domination and profitability, and thus continues to follow the imperatives of capitalist logic." 7 Thus, there are two extra dimensions to technology explaining its power over modern humans: an anthropological element (captured in Marcuse's Freudianism - control and domination as the fate of the human being in hostile nature) and the social-economic (modern capitalism). Neither dimension is captured in a definition of technology solely in terms of applied science.

In "Some Social Implications of Modern Technology," Marcuse initially differentiates technology from technics. The latter, defined as the instruments and practices of industry, transportation, communication, refers to the techniques of production and its produce, e.g., computers and automobiles, while Marcuse defines the former primarily "as a mode of production, as the totality of instruments, devices and contrivances which characterize the machine age and is thus at the same time a mode of organizing and perpetuating (or changing) social relationships, a manifestation of prevalent thought and behavior patterns, an instrument for control and domination." However, Marcuse later dismissed the difference between technology and technics. In fact, we can notice that he uses these words interchangeably in his

\footnotetext{
5 Mario Bunge, “Technology as Applied Science," in Technology and Culture, 7:3 (Summer 1966), 330.

${ }^{6}$ Ibid.

7 Douglas Kellner, Critical Theory, Marxism and Modernity (Baltimore: The Johns Hopkins University Press, 1989), 182.

${ }^{8}$ Herbert Marcuse, "Some Social Implications of Modern Technology," in Technology, War and Fascism, Collected Papers of Herbert Marcuse, Vol. 1, ed. by Douglas Kellner (London and New York: Routledge, 1998), 41.
} 
writings, especially in "Some Social Implications of Modern Technology" and One-Dimensional Man.

Marcuse apprehends technology (or technics) both as a contrivance used in the production of goods, and as a social process which facilitates control and domination. On the one hand, technology as a contrivance functions primarily as means of material production so that it will serve humanity in the procurement of basic needs for daily survival and in promoting convenient and gratifying existence. On the other, technology as a social process refers to the organization of technics (such as the technical apparatus of industry), knowledge, skills and procedures for the purpose of attaining a specific desired end. The concept technology or technics, therefore, has two dimensions in Marcuse: one where it is the simple sense analyzed by Bunge and the other having a deeper social sense. While both notions characterize technology in general, it is the latter that eminently concerns Marcuse. And, hence, it is technology as a social process which results from the systematic organization of tools for economic purposes that this paper adopts in appropriating Marcuse's critique of advanced industrial society.

Sigmund Freud has argued that these technologies are determined by Ananke or necessity as scarcity. In this way, technology appears to be necessary because it satisfies basic human needs, brings comfort to individuals, and disburdens their toil. But for Marcuse, there is another dimension to technology. For him, technology can also be a tool for social control and domination, especially under capitalism. Indeed, technology under capitalism has become a type of social control which leads to self-destruction, thus invalidating the claim that technology exists only to serve humanity better. As Marcuse argues, in the advanced industrial society, technology has become a new form of social control which demands total submission to the prevailing social order and which reduces the individuals into mere biological machines that respond to the technical processes in life. But how does technology become a tool for domination? Let us now turn to this issue.

\section{Technology as a Tool for Domination}

Marcuse claims that technology is "value-neutral" because, in point of reference to its telos, it has no fixed value. Technology is neither good nor bad. But this value-neutral technology has the propensity to become either good or bad; it has indeed the propensity to become a tool for emancipation and a tool for domination. So the value ascribed to technology is completely dependent upon the motive of the user. Therefore, if technology happens to be dominating, this is because the user has employed it in a wrong way, or if it happens to be liberating, understandably, the user has employed it in a right way. ${ }^{9}$ For Marcuse, it is crucial to understand this basic logic of technology in

\footnotetext{
${ }^{9}$ For example, the mechanical engineer who designs an automobile might be thinking of the good of humanity, but he might otherwise be thinking of how such machine would look like to suit the taste of the customer, and the managers and the salesmen manipulate this
} 


\section{TECHNOLOGY, TECHNOLOGICAL DOMINATION}

order to further comprehend its social import. For him, technology in the advanced industrial society is dominating simply because it is organized by the administrators of this society to serve their very own interests. In other words, it is the subjection of technology to politics and economics that turns technology into an instrument of domination. ${ }^{10}$ Let us discuss in detail how the capitalist social order has blocked individuals from attaining liberation via technological domination.

Technological Rationality, False Needs, and Capitalism. The capitalist mode of production which hinges primarily on modern technology has resulted in a new form of rationality-that is, technological rationality. For Marcuse, technological rationality refers primarily to the assigning of mental powers to the apparatus that calls for unconditional compliance and coordination. ${ }^{11}$ In other words, technological rationality means the subordination of thoughts to the machine process so that it is no longer the individual that directs the machine but the other way around.

According to Marcuse, technological rationality arises when, in the medium of technology, culture, politics, and the increasing power of the economic system merge into an omnipresent system which swallows up or repulses all alternatives. ${ }^{12}$ This eventually "extends to all spheres of private and public existence," integrating all authentic opposition and absorbing all alternatives. ${ }^{13}$ In this way, technology, which is originally an external power over nature, has been internalized by the individuals. Here, reason has lost its meaning because the thoughts, feelings, and actions of men are shaped by the technical requirements of the apparatus which demands compliance and adjustment. ${ }^{14}$ Thus, the human psyche is transformed into mere biological impulses which make the individual a passive agent of production as well as reduce the individual into mere spectator who adjusts to the technical processes of production. Consequently, technological rationality dissolves critical thinking and replaces it with the idea of compliant efficiency, which results in the individual's submission to the apparatus without any form of mental and physical opposition. Marcuse writes: "The world has been rationalized to such an extent, and this rationality had become such a social power that the individual could do no better than adjust himself without reservation"15 Marcuse further writes:

The idea of compliant efficiency perfectly illustrates the structure of technological rationality. Rationality is being transformed from critical force into one of adjustment

\footnotetext{
technology through massive and aggressive advertisements in the interest not of the humanity in general but maximum profit.

${ }^{10}$ See Marcuse, One-Dimensional Man, 234.

11 Marcuse, "Some Social Implications," 47.

12 Marcuse, One-Dimensional Man, xvi.

13 Ibid., 18.

14 Marcuse, "Some Social Implication," 49.

15 Ibid., 45.
} 
and compliance. Autonomy of reason loses its meaning in the same measure as the thoughts, feelings and actions of men are shaped by the technical requirements of the apparatus which they themselves created. Reason has found its resting place in the system of standardized control, production and consumption. There it reigns through the laws and mechanisms which insure the efficiency, expediency and coherence of this system. ${ }^{16}$

Under this prevailing rationality, there is no longer any place for reflection or autonomy since people are only given tasks to perform in accordance with the dictates of the apparatus. Marcuse illustrates:

A man who travels by automobile to a distant place chooses his route from the highway maps. Towns, lakes and mountains appear as obstacle to be bypassed. The countryside is shaped and organized by the highway: what one finds en route is the by-product or annex of the highway. Numerous signs and posters tell the traveler what to do and think; they even request his attention to the beauties of nature or the hallmarks of history. Others have done the thinking for him, and perhaps for the better. Convenient parking spaces have been constructed where the broadest and most surprising view is open. Giant advertisements tell him when to stop and find the pause that refreshes. And all of this is indeed for the benefit, safety and comfort; he receives what he wants. Business, technics, human needs and nature are wielded together into one rational and expedient mechanism. He will fare best who follows its directions, subordinating his spontaneity to the anonymous wisdom which ordered everything for him. ${ }^{17}$

Technological rationality has effectively and smoothly laid down its dominating power through the manipulation of needs. It transforms social needs into the individual's own thus creating attitudes which pushes the individual to obey the dictates of technology. This leads to the creation of false needs.

"False needs are those which are superimposed upon the individual by the particular interest in his repression." 18 In his early work "The Problem of Social Change in the Technological Society," Marcuse argues that false needs are social needs imposed upon the individual in the interest of the society as a

\footnotetext{
${ }^{16}$ Ibid.

${ }^{17}$ Ibid., 46.

${ }^{18}$ Marcuse, One-Dimensional, 5.
} 


\section{0}

TECHNOLOGY, TECHNOLOGICAL DOMINATION

whole. ${ }^{19}$ No matter how gratifying these kinds of needs to the individual, Marcuse maintains that the satisfaction one gets from them is not a condition to be maintained and protected since this satisfaction is always defined in terms of its conformity to the prevailing social order. Take for example the pleasure of owning a car. For sure, it would be satisfying to own a car. I can easily reach my workplace even if I am working many miles away from home. I can travel conveniently to different places I want to visit. With my car, I can spare myself from that boring and time consuming moment in the bus stop. In general, I find satisfaction in my car because it allows me greater mobility. But nowadays, it seems that the very purpose of the car is defeated. The need for efficiency and convenience is replaced by the immediate need of "identification" with the social system as a whole. The fact that an individual always replaces the model of his car as a response to a seductive advertisement or planned obsolescence strongly suggests that the car has become a false need, an instrument of domination. The same principle goes to all other needs. The spontaneous reproduction of these false needs makes the individual more insatiable and, thus, makes himself feel "...the need to buy a new automobile every other or third year, the need to relax before television...to eat enriched and soggy bread, the need to keep up with the neighbours." 20 This principle forces the individual to labor eight hours a day plus overtime, seven days a week, and four weeks a month just to meet the high standard of living set by the advanced industrial society, or the "consumerist society" as Marcuse puts it. Here, "surplus repression" is the ultimate cause of the creation of false needs. Thus, even if the individual finds greater satisfaction in this type of need, she remains locked up in a chain of technological repressions. Marcuse avers:

No matter how much such needs may have become the individual's own, reproduced and fortified by the conditions of his existence; no matter how much he identifies himself with them and finds himself in their satisfaction, they continue to be what they were from the very beginning products of a society whose dominant interest demand repression. ${ }^{21}$

Marcuse now argues vehemently that the "consumerist society" is the principal culprit of the reduction of the individual to acquiescence, of the dissolution of the revolutionary class. The "consumerist society" with its extremely high standard of living, which for Marcuse is the primordial form of control and domination in this society insofar as it is the direct offshoot of the systematic manipulation of technology, has silenced the individual and made

\footnotetext{
${ }^{19}$ Herbert Marcuse, "The Problem of Social Change in the Technological Society," in Towards a Critical Theory of Society, Collected Papers of Herbert Marcuse, Vol. 2, ed. by Douglas Kellner (London and New York: Routledge, 2001), 52.

${ }^{20}$ Ibid.

${ }^{21}$ Marcuse, One-Dimensional Man, 5.
} 
him apathetic or hostile to the idea of dissent. ${ }^{22}$ "Under the condition of a rising standard of living, non-conformity with the system itself appears to be socially useless, and the more so when it entails tangible economic and political disadvantages and threatens the smooth operation of the whole." ${ }^{23}$ The numbing effect of technology espoused with a high standard of living surely dissolves all forms of opposition in society. For how could the people resist this society if domination which appears in the guise of affluence and liberty has intruded their entire being, from their psyche down to their very instincts? How else can they say "no" if they are enjoying the repressiveness of this system?

Marcuse maintains that the administrators of this affluent consumerist society are hardly forced to justify their dominion because they deliver the goods; they satisfy the sexual and the aggressive energy of the people. ${ }^{24}$ That is why Marcuse says that "It makes no sense to talk about liberation to free men..., it makes no sense to talk about surplus repression when men and women enjoy more sexual liberty than ever before." 25 What is even worse is that the individuals in the affluent consumerist society associate unfreedom with poverty so that it would appear that it is only the poor who do not have freedom and those who enjoy the luxuries of life are called free. The submission of the individuals to the system of control and domination in the advanced industrial society is a modern form of slavery. If in ancient and medieval periods slavery is determined by forced submission, in the modern world it is exactly the opposite. According to Marcuse, slavery today is done through voluntary submission or conformism. In this manner, the individuals in the affluent consumerist society, or even those individuals in less developed societies who have adopted the values of the former, willingly but blindly cooperated with the administrators of social control and domination in the destruction of their own lives, resembling what is referred to in bioethics as "assisted suicide."

If we take a closer look at the dynamics of control and domination in the advanced industrial society, we may observe that the chasm between technological domination and political domination disappears. Marcuse observes that technological rationality and political rationality are now indistinguishable, thus, domination is administration and administration domination. In fact, Marcuse observes that at its most advanced stage, domination has functioned as administration. ${ }^{26}$ "The domination (by the politicians) has been incorporated into the daily performances and relaxation of the citizens, and the "symbols" of politics are also those of business,

22 Herbert Marcuse, Counterrevolution and Revolt (London: Allen Lane The Penguin Press, 1972), 4

${ }^{23}$ Marcuse, One-Dimensional Man, 2.

${ }^{24}$ Herbert Marcuse, "Political Preface 1966," in Eros and Civilization: A Philosophical Inquiry into Freud (United States of America: The Beacon Press, 1966), 11.

${ }^{25}$ Ibid., 12.

${ }^{26}$ Marcuse, One-Dimensional Man, 255. 


\section{TECHNOLOGY, TECHNOLOGICAL DOMINATION}

commerce, and fun." ${ }^{27}$ We may now talk about the mechanism, aside from the technological achievements, e.g., high standard of living, planned obsolescence, et cetera, that is responsible for this fusion, a mechanism that the advanced industrial society uses in effectuating a more subtle, more effective, and more efficient form of social control and domination: mass democracy.

In mass democracy the people enjoy greater political freedom than ever before. They determine their own leaders and participate in public affairs by casting their votes. They may abstain from voting, or boycott a particular product. As a collective force, mass democracy can be an effective apparatus in bringing about genuine social change. This should have been the essence of mass democracy. But in a consumerist society, Marcuse contends, mass democracy has brought not freedom but total subjection of the people. It has become the overarching mechanism of social control and domination. The people believe that they are free but in reality they are not; they were basically repressed. This is because right at the very heart of mass democracy in a consumerist society are the insatiable, consuming, and docile individuals who unconditionally obey to whatever the prevailing reality dictates. Put differently, the masses succumb to their desires by introjecting the practical values of the consumerist society. How is this made possible? Marcuse believes that this is done through mass customization and massive and aggressive advertising. Mass customization efficiently works by producing large quantities of goods and services, most often beyond what is required, and tailoring these goods and services to the specific taste and capability of the masses. The consumerist society has really all the types of goods and services that can be delivered to all classes of people. No wonder that every attempt of the Filipino intelligentsia and other progressive groups to lobby their political reforms through mass protests fails because they lacked the support of the masses. While these protesters were on the streets, the people's attention was fixated on this anesthetic show "Wowowie" or other programs of the same kind. Aside from all of this, we could also mention those exhilarating Hollywood movies, let alone the pornographic DVDs. Obviously, through the application of technology in mass customization customers find exactly what they want, that is, the false needs imposed on them by the consumerist culture. Is there something wrong with this culture? If we accept that Marcuse's analyses retain a kernel of truth today, then it would be possible to argue that there is really something wrong with this culture. In the Philippines, for example, every time

${ }^{27}$ Ibid., 103. Philippine politics is a very peculiar case. It might sound reasonable to some that during elections, all candidates resort to the mass media to make not their platforms but themselves known to the general public. My worry is not that commercial advertisements in radios and televisions are overshadowed by political ads, not that actors are becoming politicians (in fact, the Philippine senate is infested with actors like former Senators Ramon Revilla, Sr., Ramon Revilla, Jr., Lito Lapid, Tito Sotto, and incumbent Senator Jinggoy Estrada who were busy filming while the senate was off session and who slept in the senate while not filming), but it is the fact that manufacturers are beginning to use politicians as commercial modelspoliticians in the Philippines are becoming actors. They are no longer treating their job seriously. Former Senator Juan Flavier, for example, was once endorsing a rubbing alcohol. It is indeed quite hard to determine which one is politics and which one is business. 
a food chain is established in their localities (of course it goes along with the construction of malls and other amenities), e.g., Kentucky Fried Chicken, McDonald's, or Greenwich, the Filipinos rejoice since they view these establishments as concrete signs of progress and development, without thinking that these will only make them continually hungry. No wonder, obesity, which is one of the primary social problems in the U.S., is gradually becoming a serious problem in the Philippines. ${ }^{28}$ The same principle goes to the proliferation of malls and parks. The wide corridors and spacious alleys in malls draw large numbers of people, and the customized interior designs and the massive and aggressive displays of billboards forced shoppers to purchase goods which they do not need, or even do not plan to purchase. Again, even if the technology of malls obviously bankrupts the people, still they viewed these entities as concrete signs of progress and development as they "create jobs," to use the words of the politicians.

If mass customization involves mass production of goods that suit the needs or, rather, desires of the individuals, massive and aggressive advertising makes these goods sell by linking them to the instincts of the masses. In advertisements, the masses are made to desire things that they do not really need. ${ }^{29}$ Take for example a child who feels exhilarated upon seeing the big golden "M" of McDonald's or the mascot of the happy bee of Jollibee; the big billboards of Chow King or KFC which make people feel hungry even if they are not; a gigantic drizzling image of coca cola during a hot summer day. All of these bespeak of how the instincts are contrived in a way that reason is made to succumb to their overwhelming power.

If it is mass customization and aggressive advertising that both make the products appealing to the public and persuade them to purchase, for Marcuse it is functional language and positivistic thinking that play the most

28 According to Jaime Pilapil, around two million Filipinos are now obese, which means they are most likely to have heart disease, diabetes, and suffer stroke. Of the total population of Filipino women today, Pilapil adds, 20 percent are obese. And what is alarming as Pilapil's article evinces is that out of 10 deaths in the country today, 6 are caused by heart disease. To counter this alarming problem, Pilapil urges Filipinos to avoid fat-soaked fast food, such as Jollibee, Kentucky Fried Chicken, Mcdonald's, Greenwich, and the like. See Jaime Pilapil, "2M Filipinos are Overweight," in Trade Union Congress of the Philippines <http://tucpph.org/pmachine/comments.php?id=1198_0_1_0_C>, 18 January 2009. Obesity problem in the Philippines does not only haunt the adult population. Children are also victims of this problem. The Philippine Social and Environmental News reports that Filipino children are also suffering from obesity. The childhood obesity researchers are reporting more frequent cases of obesity-related diseases such as type 2 diabetes, asthma, and hypertension that once were considered adult conditions. The report shows that the primary cause of obesity in children (and adults) in the Philippines is the Filipinos' indiscriminate adoption of more western lifestyle and diet as reflected by the so-called fast food diet. See "Philippine Social and Environmental News," in Bayanihan <http://www.bayanihan.org/html/article.php/20040507114305566>, 18 January 2009.

${ }^{29}$ If we recall Freud's theory of instincts, Freud calls for the repression of the instincts simply because they are dangerous so that if released would lead to the destruction of society. But in mass democracy, these instincts are unleashed and afforded more freedom to indiscriminately and selfishly consume the goods they desire. This is exactly what Marcuse calls "repressive desublimation." 


\section{TECHNOLOGY, TECHNOLOGICAL DOMINATION}

crucial role in this process. Let us deal with these topics before proceeding to the discussion on the Great Refusal.

Ordinary Language, Positivistic Thinking, and Technological Domination. Marcuse is convinced that the efficacy of technological domination is due primarily to the type of thinking that people have in the advanced industrial society and the kind of language that binds them together. Thinking in the advanced industrial society, a society Marcuse describes as "one-dimensional," is positivistic thinking that uses ordinary language. This type of thinking is dangerous for Marcuse because it discourages critical thinking and looks only at that which is familiar, thus, the negative but redemptive dimension of thinking is kept apart. ${ }^{30}$ Contrary to philosophic thinking which is critical and dialectical, positivistic thinking is affirmative and conformist. This is because in positivism only things that can be experienced directly are considered real and those which are not directly observable are rendered unreal. The positivists lock the meaning of the word by purging it, hence, any language or term that is not functional is for the positivists meaningless. As a whole, positivistic thinking which uses functional language creates a kind of culture that affirms and legitimizes the dominant cultural values of the advanced industrial society. This positivistic culture also quells the potential tendencies of human subjects to aim for something different, to represent a state of society beyond the existing one. ${ }^{31}$

When used as the medium of mass communication, e.g., in radio, in television, in newspapers, in magazines and as the medium of discourse in general, the ordinary language of the advanced industrial society binds people together, makes them speak the same language, and makes them desire the same goods and ideals. In this way, ordinary language becomes a vehicle of control and domination. It becomes functional. In "Repressive Tolerance," Marcuse argues that this language facilitates the smooth functioning of the entire repressive system. ${ }^{32}$ Ordinary or functional language as the medium of discourse in the advanced industrial society predetermines "decisions" even before discourse happens so that what is happening is not real democratic discourse but a public announcement and imposition of "order." 33 And what is peculiar in this society is that people may not believe in its mandate, or even do not care, and yet they act accordingly. ${ }^{34}$ "One does not 'believe' the statement of an operational language but it justifies itself in action-in getting the jobs done, in selling and buying, in refusal to listen to others." 35

\footnotetext{
${ }^{30}$ Marcuse, One-Dimensional Man, 178.

31 See Douglas Kellner, "Marcuse, Art, and Liberation," in Art and Liberation: Collected Papers of Herbert Marcuse, Vol. 4, ed.by Douglas Kellner (London and New York: Routledge, 2007), 26

${ }^{32}$ Herbert Marcuse, "Repressive Tolerance," in A Critique of Pure Tolerance (Boston: Beacon Press, 1965), 94.

${ }^{33}$ Ibid., 97.

34 Marcuse, One-Dimensional Man, 103.

35 Ibid.
} 
The repressive nature of functional language is also evident in its "personal" character as it makes goods and services appear specially made "for you," us. We may see phrases in advertisements like "This is 'your' drugstore," 36 or "Manila Hotel, 'your' home away from home," or "Funeraria Gomez, 'your' funeral home," or "The dress that makes 'you' look luscious." If these goods and services are really my own, and if I am pleased with them, how can I say "no" to them? How can the individual dissent if the repressiveness of the whole system enhances greater material satisfaction than ever before?

In the political sphere, functional language reveals its dominating character when it becomes the language of Law and Order validated by the courts and the police. According to Marcuse, this language does not only define and condemn the Enemy but also creates the Enemy. ${ }^{37}$ And “...this creation is not the Enemy as he really is but rather as he must be in order to perform his function in the Establishment." 38 As a result, the Enemy always appears as evil and everything it says is propaganda. Take for example how the US and British governments produce the image of the Islamic world as "axis of evil" by associating its identity with violence, e.g., suicide bombings. Today, the term Islam or Muslim appears to have become identical with the term "terrorist." To take another example, contemporary this time to Marcuse, he was particularly struck by the Vietnam War. For him, many of us who had watched movies about the Vietnam War would have had despised the Viet Cong and lauded the Americans. One of the reasons is that the Viet Cong attacked the Americans during the dead of the night and killed American soldiers, while the Americans only attacked in broad daylight and didn't disturb the sleep of the enemy. ${ }^{39}$ When this was publicized, especially in broadcast media, the result was that people in the world sympathized with the Americans.

The abbreviation of terms is something that also struck Marcuse as a sign of the functionalization of language. It is one of the cunning techniques of the advertisement industry to repress the questioning mind of the people. ${ }^{40}$ Marcuse writes: "NATO does not suggest what North Atlantic Treaty Organization says, namely, North Atlantic Treaty Organization, in which case one might ask questions about the membership of Greece and Turkey." "The abbreviation denotes that the meaning is fixated, doctored, loaded. Once it has become a vocable, constantly repeated in general usage, 'sanctioned' by the intellectuals, it has lost all cognitive value and serves merely for recognition of an unquestionable act." ${ }^{, 42}$ Marcuse also says:

\footnotetext{
${ }^{36}$ Ibid., 92.

${ }^{37}$ Herbert Marcuse, An Essay on Liberation (London: Allen Lane The Penguin Press, 1969), 74

38 Ibid.

${ }^{39}$ Ibid., 75.

${ }^{40}$ Marcuse, One-Dimensional Man, 93.

${ }^{41}$ Ibid., 94.

42 Ibid.
} 


\section{TECHNOLOGY, TECHNOLOGICAL DOMINATION}

The telescoping and abridgement of syntax which cuts off development of meaning by creating a fixated images which impose themselves with an overwhelming and petrified concreteness is a well-known technique of the advertisement industry, where it is methodically used for "establishing an image" which sticks to the mind and to the product, and helps to sell the men and the goods. ${ }^{43}$

The above discussion finally explains in full why and how technology has become a tool for control and domination in advanced industrial society vis-à-vis mass democracy, mass customization, massive and aggressive advertising, functional language, and positivistic thinking. Let us now proceed to the discussion on how Marcuse addresses this issue.

\section{Technology as a Tool for Emancipation}

Though Marcuse believes that technology becomes the new form of social control and domination in the advanced industrial society, he is not saying that domination necessarily follows whenever there is technology. For, in the first place, technology can also be a very decisive tool for emancipation, especially in liberating humanity from material necessity. In One-Dimensional Man, Marcuse maintains that it is not technology that is to blame for the enslavement of man and the perpetuation of the struggle for existence but the way in which men treat technology and the way they organized societal labor. ${ }^{44}$ And he echoes this conviction in his work An Essay on Liberation. He puts it interrogatively: "Is it still necessary to state that not technology, not technique, not the machine are the engines of repression, but the presence, in them, of the masters who determine their number, their life span (planned obsolescence), their power, their place in life, and the need for them?"45 He adds:

Is it still necessary to repeat that science and technology are the great vehicles of liberation and that it is only their use and restriction in the repressive society which makes them into vehicle of domination? Not the automobile is repressive, not the television is repressive, not the household gadgets are repressive, but the automobile, the television, the gadgets which, produced in accordance with the requirements of profitable exchange, have become part and parcel of the people's own existence, own "actualization." 46

\footnotetext{
43 Ibid., 91.

${ }^{44}$ Marcuse, One-Dimensional Man, 144.

${ }^{45}$ Herbert Marcuse, An Essay on Liberation (London: Allen Lane The Penguin Press,

${ }^{46} \mathrm{Ibid}$.
} 1969), 12. 
This means that domination comes into the fore when technology is used for the maintenance of the capitalist system. It is, therefore, technological rationality rather than technology itself that defines the overwhelming power of domination. Insofar as technological rationality is historical by nature, this means that men can always reshape society to their advantage and carry out the project of emancipation by redirecting the course of technology, that is, by switching from technological rationality to a kind of rationality that promotes freedom and happiness. But given the fact that the power of technological domination is so formidable in the advanced industrial society, would there be any chance for the dawning of the project of emancipation? And if the answer is in the positive, by what means can it be achieved?

Marcuse always believes that emancipation is attainable and the means is practicable. However, he admits that it is a task which is almost completely bereft of hope. As a matter of fact, Marcuse becomes quite pessimistic towards the end of One-Dimensional Man. He observes that the chance of the historical alternative, that is to say, of radical social change is bleak. The more the advanced industrial society delivers the goods and alleviates the burden of life the more "refusal" becomes unreasonable. ${ }^{47}$ But this moment of despondency did not push Marcuse to the brink of hopelessness. As he has reached the point of no return, the struggle goes on.

The Great Refusal. Marcuse understands the Great Refusal as a kind of "negativity" both in thought and action which enables the individuals to transform their present needs, sensibility, consciousness, values, and behaviour into a new radical sensibility, a sensibility that does not tolerate injustice and that which resists and opposes all forms of control and domination. Douglas Kellner contends that for Marcuse, the Great Refusal is a political individualistic refusal and revolt against the system of domination and oppression exacted by the bourgeois society. ${ }^{48}$ But despite the fact that Marcuse emphasizes individualistic refusal and revolt, the Great Refusal is in the end a "collective refusal and revolt" aimed both at overthrowing the system of domination and oppression and the realization of a radical total social change, the realization of a socialist, non-repressive, free, and happy society. In One-Dimensional Man, Marcuse avers that it is only the Great Refusal that expresses a "truly revolutionary mode of opposition." 49

Why the Great Refusal? If we rehearse here Marcuse's psychoanalytic turn, he argues that Ananke or the reality principle is no longer necessary. ${ }^{50}$ The need to work long and hard in order for man to survive or for civilization to thrive has been invalidated by the very achievements of the advanced industrial society. This society has reached a stage of necessary abundance wherein people are no longer obliged to work long and hard, but work less and

\footnotetext{
47 Marcuse, One-Dimensional Man, 255.

48 Douglas Kellner, Herbert Marcuse and the Crisis of Marxism (London and Berkley: MacMillan Press and University of California Press, 1984), 279.

${ }^{49}$ Marcuse, One-Dimensional Man, 255.

50 See Jeffry Ocay, "Eroticizing Marx, Revolutionizing Freud: Marcuse's Psychoanalytic Turn," in KRITIKE: An Online Journal of Philosophy, 3:1 (June 2009), 10-23.
} 


\section{TECHNOLOGY, TECHNOLOGICAL DOMINATION}

enjoy more. But Marcuse observes that the capitalist mode of production and organization has retained Ananke by replacing the "reality principle" with the "performance principle." The performance principle manipulates instinctual desires through the creation of false needs as soon as the old ones are satisfied, thus making individuals in the capitalist society to work more and perform well. And the capitalist society has effectively done this through the privatization of industries where profits gravitate only to the few, the valorization of social virtues like "hard work" and success through competition, and the reward system, e.g., giving incentives and commissions to top-performing employees, giving plaque of recognition to employees for being dubbed as the "employee of the month," or "employee of the year," or "faculty of the year," and giving tokens, for example a golden ring, to loyal employees for reaching 10 or 15 years of service (or rather 10 or 15 years of servitude?). The point Marcuse would like to show is that "surplus repression" which is created by the capitalist society is absolutely unnecessary, thus, it has to be "refused"; the individuals in the advanced industrial society must say "NO" to this surplus repression. This is precisely the raison d'e $\mathrm{e}$ tre of the Great Refusal.

The Great Refusal is not simply an act of refusal for refusal's sake. As I have argued above, the Great Refusal is above all a struggle towards emancipation. It is a struggle towards the realization of a socialist, nonrepressive, free, and happy society where people are freed from technological domination and at the same time enjoying the free play of their faculties. ${ }^{51}$ And indeed enjoy the benefits from modern industry and technology. This kind of liberation for Marcuse is primarily liberation of the senses from reification. He calls it "radical sensibility." Marcuse believes that the senses are central in the process of liberation because ."..the emancipated senses would repel the instrumentalist rationality of capitalism while preserving and

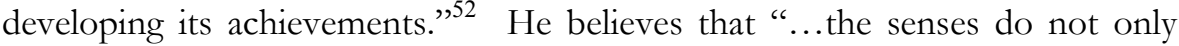
'receive' what is given to them, in the form in which it appears, they do not 'delegate' the transformation of the given to another faculty (the understanding); rather, they discover or can discover by themselves, in their 'practice', new (more gratifying) possibilities and capabilities, forms and qualities of things and can urge and guide their realization." 53 But Marcuse's understanding of the term "senses" does not only refer to the internal and external organs as organs of perception. Rather, the term "senses" refer to the human body as a whole and also includes rationality. ${ }^{54}$ Thus, the phrase "liberation of the senses" means "liberation of the human body." This is because the direct object of technological domination is precisely the human

51 For Marcuse, technological domination is the leading form of social control and domination in the advanced industrial society where "reification" and "alienation of labor" are retained. Thus, when we say "technological domination" it means the conglomeration of all forms of social control and domination through the mediation of technology.

52 Marcuse, Counterrevolution and Revolt, 64.

${ }^{53}$ Ibid., 17.

${ }^{54}$ Marcuse, Eros and Civilization, 163. 
body. Inasmuch as technological domination exploits the body through reification, and if reification of the senses is the ultimate cause of the subjection of man, then it is the liberation of the senses that would bring rupture with this continuum of control and domination in the advanced industrial society. It is the liberation of the senses that would engender a free and happy society. Thus, Marcuse insists that to liberate humanity, the liberation of the senses should come first. ${ }^{55}$ And he adds: "It is this primary experience of the senses itself which must change radically if social change is to be radical, qualitative change." 56

The first step necessary for the realization of this kind of liberation is the reduction of the number of working hours to the minimum or even abolishing human work through complete automation, that is, letting the machine do the work on behalf of the workers. Marcuse argues: "The reduction of the working day to a point where the mere quantum of labor time no longer arrests human development is the first requisite of freedom."57 When this moment is reached, then man begins to see the dawn of liberation because "surplus repression" is removed. But this requires first and foremost the Great Refusal.

Marcuse portrays "liberation" through the images of the Greek gods Orpheus and Narcissus. Orpheus is an archetype of a poet as liberator who establishes a higher order in the world, an order without repression and a creator who brings peace and salvation by pacifying man and nature, not through force but through song; Orpheus's language is song and his work play, while Narcissus is the symbol of beauty, of art; his life is that of beauty and his existence is contemplation. ${ }^{58}$ In the persons of Orpheus and Narcissus, art, freedom, and culture are eternally combined. Unlike Prometheus who symbolizes toil, productivity, and progress through repression, Orpheus and Narcissus symbolize work as play. ${ }^{59}$ Unlike Prometheus who curses Pandora (the female principle which symbolizes sexuality and pleasure) because her beauty and the happiness she promises are fatal to work and civilization; Orpheus and Narcissus, on the other hand, celebrate sexuality. ${ }^{60}$ Orpheus and Narcissus reconcile Eros and Thanatos; they celebrate the body and refuse to succumb to the performance principle. The Orphic and Narcissistic images are indeed symbols of the Great Refusal-a refusal to the order of repression, a refusal which aims at liberation. ${ }^{61}$ Marcuse cites Margaret Mead's interpretation of the Arapesh culture to further describe the world of Orpheus and Narcissus, a world that is not to be mastered and dominated but as a garden which can grow alongside the growth of human beings:

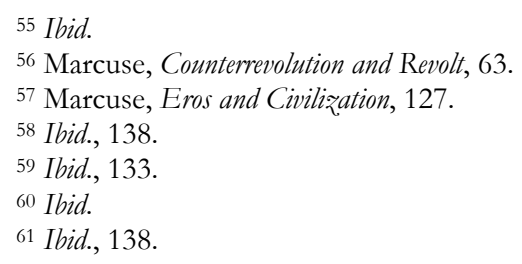


To the Arapesh, the world is a garden that must be tilled, not for one's self, not in pride and boasting, not for hoarding and usury, but that the yams and the dogs and the pigs and most of all the children may grow. From this whole attitude flow many of the other Arapesh traits, the lack of conflict between the old and the young, the lack of any expectation of jealousy and envy, the emphasis on cooperation. ${ }^{62}$

Marcuse's notion of the Great Refusal as the most appropriate and practicable means to address the problem of social control and domination has taken many forms. We can notice this in the switching of tone in his works from One-Dimensional Man down to his last work the Aesthetic Dimension. In OneDimensional Man, "Repressive Tolerance," and An Essay on Liberation, Marcuse advocates confrontation politics, while in his Counterrevolution and Revolt, he advocates United Front among the New Left. And, finally, in The Aesthetic Dimension, Marcuse resorts to "art" and argues that "art" is the ultimate form of the Great Refusal. While some scholars argue that Marcuse's The Aesthetic Dimension abandons the idea of confrontation politics and United Front, I believe the contrary. The shift from confrontation politics to United Front then finally to art is necessary for Marcuse because the social condition changes. The change of tactic, therefore, is not to be viewed as an act of abandonment of previous strategies. It is basically a renewal of this tactic to suit the demand of the time. And so I argue that this is exactly what Marcuse did, and in doing so, I believe he retains the negating aspects of "confrontation politics" and "United Front."

For sure, the Great Refusal is a call for "revolution" which is necessary in the sense that liberation requires a rupture in history and this rupture can only be done through revolution. ${ }^{63}$ But it must be noted that Marcuse does not favour violence or bloody revolution. The kind of revolution that he envisions is completely different from what we have witnessed in history, for example, the French Revolution, the Bolshevik Revolution, and the Long March in China. This revolution is carried forward not by armed individuals but by the individuals of "new sensibility." This revolution is

...driven by the vital need to be free from the administered comforts and the destructive productivity of the exploitative society, freed from smooth heteronomy, a revolution which, by virtue of this "biological" foundation, would have the chance of turning quantitative technical progress into qualitatively different ways of life-precisely because it would be a revolution occurring at a high level of material and intellectual

\footnotetext{
${ }^{62}$ Marcuse, Eros and Civilization, 173.

${ }^{63}$ Marcuse, Essay on Liberation, 19.
} 


\section{J. OCAY 71}

development, one which would enable man to conquer scarcity and poverty. ${ }^{64}$

In Counterrevolution and Revolt, Marcuse argues that this revolution involves the "new sensibility," i.e., the transformation of the cultural and material basis of the society, the needs and aspirations of the individuals, and their consciousness and sensibility. ${ }^{65}$ This "new sensibility" is revolutionary because it militates against technological domination. It militates against the numbing effect of the functional language of the consumerist society and at the same time shatters the kind of "false consciousness" that this language engenders. However, as there are always exceptions to the rule, Marcuse accepts, albeit hesitantly, the possibility of violent revolt. In "Repressive Tolerance," Marcuse writes:

If they (the oppressed and overpowered minorities) use violence, they do not start a new chain of violence but try to break an established one. Since they will be punished, they know the risk, and when they are willing to take it, no third person, and at least of all the educators and intellectuals, has the right to preach them abstention. ${ }^{66}$

And when asked whether violent revolt would bring any good, he answers:

With all the qualification of the hypothesis based on an 'open' historical record, it seems that the violence emanating from the rebellion of the oppressed classes broke the historical continuum of injustice, cruelty, and silence for a brief moment, brief but explosive enough to achieve an increase in the scope of freedom and justice, and a better and more equitable distribution of misery and oppression in a new social system-in one word: progress in civilization. ${ }^{67}$

${ }^{64}$ Ibid., 19.

${ }^{65}$ Marcuse, Counterrevolution and Revolt, 16-17.

66 Marcuse, "Repressive Tolerance," 117.

${ }^{67} \mathrm{Ibid}$., 107. I do not want to advocate violence in this paper, but it is interesting to note that most great nations in the past and even today were upshots of violent upheavals. Whether we like it or not history is always a history of wars, of violent upheavals. We may take for example how the French Revolution reshaped not only the socio-economic and political landscape of France, but also that of entire Europe, even the world, perhaps. The deposition of the French monarch through public execution, which also replaced absolute monarchy with the rule of the people, had paved the way for the institutionalization of the "inalienable rights" of citizens, of which the French had never enjoyed before. We may also highlight how the United States of America emerged as a world superpower, and now as a "globo cop," from the two great wars, i.e., the British-American War of 1812 and the American Civil War of 1861-1865. Equally important is the case of China. It might be unsound to attribute her economic power to 


\section{TECHNOLOGY, TECHNOLOGICAL DOMINATION}

With this novel form of revolution, the Marxist notion of "proletariat" as the sole agent of radical change has been disqualified. This now justifies Marcuse's claim, which I have discussed in the early part of this paper, that it is the individual who is disposed to radical action who can be the agent of revolution-the individual with the new sensibility. This individual is not the ascetic individual, the asocial and apolitical Dasein of Heidegger, but the politically conscious individual. And when this politically conscious individual forms alliance with other individuals of the same consciousness, a "collective radical action" ensues. Marcuse calls this alliance the New Left. This New Left is not a single organization with the same ethos like the Communist Party of the Philippines or the National Liberation Fronts in general. Rather, it refers to the different minority groups like the students' movement, women's movement, labor unions, and other politically inclined groups that struggle for liberation. For Marcuse, these forces are concrete expressions of the Great Refusal because they define the limits of the established societies and signal the impending rupture of history. ${ }^{68}$

Because control and domination in the advanced industrial society has become an overwhelming force that debilitates the individual, Marcuse insists that it must be shattered, and this can be done only through radical politics, a political practice of methodical disengagement from and refusal of the established society. ${ }^{69}$ "Such a practice involves a break with the familiar, the routine ways of seeing, hearing, feeling, understanding...."70 Thus, the New Left, which for Marcuse is the only possible counterforce in the advanced industrial society, must "...assume the vast task of political education, dispelling the false and mutilated consciousness of the people so that they themselves experience their condition, and their ambitions, as vital needs and apprehend the ways and means of their liberation." ${ }^{, 71}$ Thus, the revolution driven by the new sensibility must be brought to the political arena; however, it is both a political and a cultural struggle. This is now what Marcuse would have us do: refuse, resist, and repel technological control and domination. The Great Refusal is indeed expressed in this way.

Despite the fact that Marcuse has a slight slant in favor of violent revolt, he made it very clear that in a highly advanced society this tactic should not be employed. A struggle which attempts to seize power directly from the centers of political control, Marcuse says, should not be resorted to because in

the Chinese Revolution, otherwise known as the Long March of 1934 that installed Mao Zedong as the first President of the People's Communist Republic of China, but no one can deny the fact that it is the nationalization of the major industries, which were previously owned by foreign companies, that boosted the economy of China during the second half of the $20^{\text {th }}$ century. China's economic successes today (although there are downturns because of the recent global economic crunch) can be partly or, rather, mostly, attributed to the economic policies of the revolutionary government of Mao Zedong.

68 Marcuse, Essay on Liberation, 6.

${ }^{69}$ Ibid.

${ }^{70}$ Ibid., 6.

${ }^{71}$ Marcuse, Counterrevolution and Revolt, 28. 
the advanced industrial society the military and police power have been so organized in the hands of an effectively functioning government, thus, the chance of winning is a remote possibility. ${ }^{72}$ And, more importantly, such tactic surely would not draw support from the working class due primarily to the prevalence of reformist consciousness among them. ${ }^{73}$ What is the alternative? The best alternative, Marcuse maintains, is the "...control of the mode of production, a redirection of the mode production toward the satisfaction of the senses and imagination of the individuals. This would weaken the Establishment and eventually leads to its demise and the triumph of socialism."74 And this alternative is found in "art."

Art as the Ultimate form of the Great Refusal. It might appear, as some scholars argue, that Marcuse had abandoned his advocacy of confrontation politics and United Front in the 1960s and early 1970s and resorted to art in the late 1970s. But this assumption does not hold water. While it is true that Marcuse considers "art" to be the ultimate form of the Great Refusal, any assumption that he had put this argument only in his last work The Aesthetic Dimension would do injustice to Marcuse. As early as the writing of Eros and Civilization in early 1950s, Marcuse had already claimed that "art" is the ultimate form of the Great Refusal. Marcuse writes: "This Great Refusal is a protest against unnecessary repression, the struggle for the ultimate form of freedom - 'to live without anxiety'. But this idea could be formulated without punishment only in the language of art." 75 In One-Dimensional Man, Marcuse repeats this claim. He said that art has the power of negation, ${ }^{76}$ and, in its most advanced form, it is the Great Refusal-the refusal of that which is. ${ }^{77}$ The same argument is found in An Essay on Liberation: "The Great Refusal, which is the 'new sensibility', is the ascent of the life-instincts over aggressiveness and guilt." "78 This again is best incarnated in the work of art. And in Counterrevolution and Revolt, Marcuse argues again that emancipation requires the language of art. ${ }^{79}$ What I would like to argue here is that "art" as the ultimate form of the Great Refusal is the very form of the political struggle for liberation. Again, I argue that Marcuse never abandons his advocacy of "radical politics." What Marcuse does is amplify radical politics by giving it its form: art. With this, we could rightly infer that art and radical politics go hand

72 Ibid., 43.

73 Ibid. Although Marcuse is convinced that the working class is no longer the sole agent of the revolution, he continues to believe that they remain the most decisive revolutionary force. The acquiescence or complicity of the working class to the system of control and domination does not mean complete dissolution of opposites in the advanced industrial society. This dissolution is only a momentary one. Marcuse continues to believe that the working class remains a revolutionary class. The power to subvert the oppressive society lies dormant in their very consciousness but so ripe for explosion once ignited.

${ }^{74}$ Marcuse, Counterrevolution and Revolt, 43.

${ }^{75}$ Marcuse, Eros and Civilization, 125.

${ }^{76}$ Marcuse, One-Dimensional Man, 62.

${ }^{77}$ Ibid., 63.

78 Marcuse, Essay on Liberation, 23-24.

${ }^{79}$ Marcuse, Counterrevolution and Revolt, 79. 


\section{TECHNOLOGY, TECHNOLOGICAL DOMINATION}

in hand in the struggle for liberation. It is art that gives the form of a socialist, non-repressive, free, and happy society, while it is radical politics that realizes this vision.

Because liberation for Marcuse is the liberation of the senses, that is, liberation of the "body," from false consciousness or reification, then there is no other form that could actualize this notion of liberation than art itself. "Against all fetishism of the productive forces, against the continued enslavement of individuals by the objective conditions (which remain those of domination), art represents the ultimate goal of all revolutions: the freedom and happiness of the individual." political potential of indicting and subverting the established order through a refusal to obey its language, its order, its conventions, and its images, ${ }^{81}$ and; second, art invokes the beautiful image of liberation as can be seen in Marcuse's portrayal of the world of Narcissus and Orpheus as one of joy and fulfillment, a world where work has become play and Eros is released from repression. ${ }^{82}$ For Marcuse, this is the precondition of the liberation of the senses. This is based on the four-fold true functions of art, namely: 1) to negate the present condition of society, 2) to anticipate the trends of the future, 3) to criticize destructive or alienating trends, and 4) to suggest "images" of creative non-alienating trends. ${ }^{83}$ In other words, art negates the prevailing system of control and domination because it awakens and enlightens the repressed rationality and sensibility of man. Art projects the "beautiful" image of liberation and directs these repressed rationality and sensibility to this state of affairs. In this way, art becomes a revolutionary factor (but not as an instrument of revolution) which breaks the mystified and petrified social reality and opens the horizon of change, of liberation. ${ }^{84}$ This would logically terminate "...in the emergence of another reason, another sensibility, which defy the rationality and sensibility incorporated in the dominant social institutions." 85 Thus, liberation of the senses also entails the liberation of reason. This kind of reason and sensibility which Marcuse describes as "sensuous reason" and "rational sensuousness" 86 is the true image of liberation and is possible only through genuine art. In a dialogue with Richard Kearney, Marcuse says:

\footnotetext{
80 Herbert Marcuse, The Aesthetic Dimension: Toward a Critique of Marxist Aesthetics (London: Macmillan Press, 1979), 69.

${ }^{81}$ Richard Kearney, Dialogues with Contemporary Continental Thinkers, The Phenomenological Tradition (London: Manchester University Press, 1984), 74.

82 Marcuse, Eros and Civilization, 133-144.

83 Ibid., 76-77.

${ }^{84}$ Marcuse, Aesthetic Dimension, xi.

85 Ibid., 7.

86 See Marcuse, Eros and Civilization, 148. "Sensuousness is a Marcusean term which denotes the liberation of the senses. The phrases "sensuous reason" and "rational sensuousness" are for Marcuse the principle of a non-repressive society. Reason here is no longer viewed as instrumental, that is to say, as instrument of domination, but one that is united with the senses. Unlike the Platonic psychology where reason denounces and represses the instincts, in rational sensuousness reason is alloyed with the instincts in the celebration of Eros.
} 


\section{J. OCAY 75}

I believe that you cannot have the liberation of human sensitivity and sensibility without a corresponding liberation of the rational faculty... of man. Any liberation effected by art signifies therefore, a liberation of both the senses and reason from their present servitude. ${ }^{87}$

Now, if we recall the discussion on Marcuse's engagement with Freud's theory of instincts, we notice that Marcuse insists that Eros must not be repressed through the postponement of its gratification so that mind and body, reason and the senses would become the vehicles of liberation. Art as the ultimate form of the Great Refusal is logically connected to this. The projection of the "beautiful" image of liberation is basically the affirmation and celebration of Eros, of the life-instincts and at the same time accord them immediate gratification. The non-repressive, free, and happy image of the world of Orpheus and Narcissus is, therefore, the hidden meaning of the notion of "liberation of the senses." This now completes the answer to the question why art is the ultimate form of the Great Refusal.

At first glance, it looks as if art is an instrument of radical politics. But Marcuse warns us that art cannot be united with radical politics. Art and radical politics are two different things. Art and radical politics work in a dialectical fashion-art gives radical politics its form, while radical politics gives art its content, and this dialectic is permanent. As I have mentioned above, art only gives the form of a non-repressive, free, and happy society, which means that art cannot translate its vision into reality, whereas it is radical politics that realizes this vision. If art is the ultimate form of the Great Refusal, why not use art as an instrument of radical politics, as a political instrument in the struggle for liberation, e.g., using art as propaganda? This is dangerous for Marcuse because art in this manner is standardized art and becomes ideological; it loses its negating power. When art is used as an instrument to effect mass conversion of sensibility and consciousness, art abuses its four-fold true functions. ${ }^{88}$ That is why Marcuse disagrees with Walter Benjamin who urges that popular art or mass culture, particularly the cinema, should be used as a political instrument in a socialist revolution. ${ }^{89}$

The idea that art and radical politics work in a dialectical fashion signifies that the struggle for liberation is permanent. There is not one single moment wherein art has attained its ultimate goal and man ceases to do radical politics. What Marcuse believes is that once liberation of the senses is attained, new forms of problems may arise, and so on. Thus, art and radical politics shall eternally posit their negating power. Marcuse puts it brilliantly:

\footnotetext{
${ }^{87}$ Kearney, Dialogues, 75.

88 Ibid., 76.

${ }^{89}$ Walter Benjamin, "The Work of Art in the Age Mechanical Reproduction," cited in Jonathan Joseph, Social Theory: Conflict, Cohesion and Consent (Edinbugrh: Edinburgh University
} Press, 2003), 131. 


\section{TECHNOLOGY, TECHNOLOGICAL DOMINATION}

Art and politics will never finally coalesce because the ideal society which art strives for in its negation of all alienated societies presupposes an ideal reconciliation of opposites, which can never be achieved in any absolute or Hegelian sense. The relationship between art and political praxis is therefore dialectical. As soon as one problem is solved in a synthesis, new problems are born and so the process continues without end. The day when men try to identify opposites in an ultimate sense, thus ignoring the inevitable rupture between art and revolutionary praxis, will sound the death-knell for art. Man must never cease to be an artist, to criticize and negate his present self and society and to project by means of his creative imagination alternative "images" of existence. He can never cease to imagine for he can never cease to change. ${ }^{90}$

Finally, we may now talk about technology as a tool for emancipation. In order for technology to be a tool for emancipation, it has to reconstruct its direction and goal in accord with the "new sensibility" - the demands of Eros. ${ }^{91}$ Then the liberated consciousness made possible by the dialectical interplay between art and radical politics would promote a kind of technology that is free to project and design an image of human existence without exploitation and toil. ${ }^{92}$ The automation or even complete automation that technology promises would make this happen. Man no longer needs to work long and hard, but work less and enjoy more. With this, things would become easier and prettier to man and at the same time would satisfy all his vital needs. And when this happens man would be free to pursue the things necessary for the attainment of his "complete being." Here, man truly enjoys the free play of his faculties, the very condition that "art" dreams of. In this way, technology assumes the features of art, especially the beautiful image of liberation it promises. But, again, for Marcuse, all of this can be brought to fruition if and only if the individuals in the advanced industrial society practice the Great Refusal.

Department of Philosophy, Silliman University, Philippines Department of Philosophy, Macquarie University, Australia

\footnotetext{
${ }^{90} \mathrm{Ibid} ., 87$.

${ }^{91}$ Marcuse, Essay on Liberation, 19.

92 Ibid.
} 


\section{References}

"Philippine Social and Environmental News," in Bayaniban <http://www.bayanihan.org/html/article.php/20040507114305566>, 18 January 2009.

Benjamin, Walter, "The Work of Art in the Age Mechanical Reproduction," cited in Jonathan Joseph, Social Theory: Conflict, Cohesion and Consent (Edinbugrh: Edinburgh University Press, 2003).

Bunge, Mario, "Technology as Applied Science," in Technology and Culture, 7:3 (Summer 1966).

, "The Philosophical Richness of Technology," in PSA: Proceedings of the Biennial Meeting of the Philosophy of Science Association, 2 (1976).

Heidegger, Martin, The Question Concerning Technology and Other Essays, trans. by William Lovitt (New York and London: Garland Publishing, 1977).

Kearney, Richard, Dialogues with Contemporary Continental Thinkers, The Phenomenological Tradition (London: Manchester University Press, 1984).

Kellner, Douglas, "Marcuse, Art, and Liberation," in Art and Liberation: Collected Papers of Marcuse, Herbert, Vol. 4, ed.by Douglas Kellner (London and New York: Routledge, 2007).

, Critical Theory, Marxism and Modernity (Baltimore: The Johns Hopkins University Press, 1989).

, Herbert Marcuse and the Crisis of Marxism (London and Berkley: MacMillan Press and University of California Press, 1984).

Marcuse, Herbert, "Political Preface 1966," in Eros and Civilization: A Philosophical Inquiry into Freud (United States of America: The Beacon Press, 1966).

, "Repressive Tolerance," in A Critique of Pure Tolerance (Boston: Beacon Press, 1965).

, "Some Social Implications of Modern Technology," in Technology, War and Fascism, Collected Papers of Marcuse, Herbert, Vol. 1, ed. by Douglas Kellner (London and New York: Routledge, 1998).

"The Problem of Social Change in the Technological Society," in Towards a Critical Theory of Society, Collected Papers of Marcuse, Herbert, Vol. 2, ed. by Douglas Kellner (London and New York: Routledge, 2001). 1969).

, An Essay on Liberation (London: Allen Lane The Penguin Press, Counterrevolution and Revolt (London: Allen Lane The Penguin Press, 1972).

, The Aesthetic Dimension: Toward a Critique of Marxist Aesthetics (London: Macmillan Press, 1979).

Ocay, Jeffry V., "Eroticizing Marx, Revolutionizing Freud: Marcuse's Psychoanalytic Turn," in KRITIKE: An Online Journal of Philosophy, 3:1 (June 2009). 


\section{TECHNOLOGY, TECHNOLOGICAL DOMINATION}

"Heidegger, Hegel, Marx: Marcuse and the Theory of Historicity," in KRITIKE: An Online Journal of Philosophy, 2:2 (December 2008).

Pilapil, Jaime, "2M Filipinos are Overweight," in Trade Union Congress of the Philippines $<$ http://tucpph.org/pmachine/comments.php?id=1198_0_1_0_C>, 18 January 2009. 